\author{
Izabela Kapera \\ The University of Physical Education in Krakow \\ Faculty of Tourism and Leisure \\ Department of Tourism and Leisure \\ lowczowska@poczta.onet.pl
}

\title{
MOTIVES AND EXPECTATIONS OF STUDENTS FROM UKRAINE WITH RESPECT TO HIGHER EDUCATION IN POLAND IN THE FIELD OF TOURISM
}

\begin{abstract}
The purpose of the research is to analyze the motivation and expectations of students from Ukraine with respect to higher education (HE) in the field of tourism. A survey questionnaire was created to be used by a target group in order to obtain their views. Research has shown that the main motive $(60 \%)$ for studying in Poland was the desire to study and work at the same time. In reality HE students combined degree study and work in even more cases, and 58\% of the work involved the tourism industry. Almost half of the students surveyed intend to remain in Poland following graduation. Those who expressed a desire to leave for other countries most often identified Spain and Germany. At the same time, most stated that they would like to work in professions associated with tourism including work in travel agencies and hotels.
\end{abstract}

Keywords: tourism, higher education, HE students, foreign, Ukraine.

\section{INTRODUCTION}

The current demographic situation in Poland is such that universities need an influx of students from abroad in order to maintain operations at desirable levels. Other factors that drive the influx of such HE students are globalization and the internationalization of higher education across the world. HE students are now able to cross national boundaries easily and take part in European Union educational programs. National governments are currently looking at students differently and view them as an opportunity to drive economic growth. HE admission boards now view the influx of foreign students as an opportunity to enhance the international standing of their institutions (DŁUGOSZ 2015). Hence, it appears sensible to learn about the expectations of young people coming to Poland to study. As of November 30th 2016, the number of HE students in Poland stood at 1,348,822, and this included 65,793 foreign students (GUS 2017). More than half of those studying in Poland are students from Ukraine $(35,584)$ (GUS 2017).

Tourism is one of the most popular HE majors selected by students in Poland. The aim is to analyze the motives and identify the expectations of students from Ukraine in the field of tourism studies at HE institutions and universities in Poland. The various issues associated with these students and their education are increasingly often being studied (BERGIER \& BERGIER, TsOS 2012, DŁUGOSZ 2015, GIERKO 2015, GÓRSKA 2015, BIERÓWKA 2016, GAWRON 2016, LEŚNIAK 2016, WOJTULEWSKI 2016). Yet no papers are available on this issue with respect to HE in the field of tourism. The current study is divided into three parts: (1) foreign students in Poland today; (2) methods and research results derived from a survey questionnaire; (3) discussion of research results with respect to the available research literature.

\section{FOREIGN STUDENTS IN POLAND}

The number of foreign students in Poland has increased substantially in the last few years. For comparison, the number in the 1995/96 academic year was slightly higher than 5,000, while ten years later the number had doubled. Within another decade, the figure had exceeded 57,000 (Table 1).

The largest number of foreign students were registered in the cities of Warsaw, Kraków, Lublin, and Wrocław. More than 57,000 foreign HE students 
were on record in Poland in the 2015/16 academic year, with most arriving from European countries. The top ten sending HE students to Poland were Ukraine, Belarus, Norway, Spain, Sweden, Turkey, Czech Republic, Russia, Germany, and Lithuania. Students from more than 150 countries are known to come to Poland for their higher education and more than half are Ukrainian, constituting the largest group $(52,003$ individuals) (ŁYSIENIA, ed. 2015). In addition, the number of Ukrainian students in Poland is increasing at the highest rate among the various groups. In 1998 the figure was 868, while in 2003 it had increased by more than a thousand (KORCZYŃSKA \& KAŹMIERKIEWICZ 2005). The number of Ukrainian students has continued to increase quite rapidly ever since (Table 2).

Table 1. Foreign students at HE institutions and universities in Poland

\begin{tabular}{|l|c|}
\hline $\begin{array}{c}\text { Academic } \\
\text { year }\end{array}$ & $\begin{array}{c}\text { Number of foreign students at HE } \\
\text { institutions and universities } \\
\text { in Poland }\end{array}$ \\
\hline $1995 / 96$ & 5,202 \\
\hline $2000 / 01$ & 6,563 \\
\hline $2001 / 02$ & 7,380 \\
\hline $2002 / 03$ & 7,608 \\
\hline $2003 / 04$ & 8,106 \\
\hline $2005 / 06$ & 10,092 \\
\hline $2006 / 07$ & 11,753 \\
\hline $2007 / 08$ & 13,695 \\
\hline $2008 / 09$ & 15,862 \\
\hline $2009 / 10$ & 17,000 \\
\hline $2010 / 11$ & 21,474 \\
\hline $2011 / 12$ & 24,253 \\
\hline $2012 / 13$ & 29,172 \\
\hline $2013 / 14$ & 35,983 \\
\hline $2014 / 15$ & 46,101 \\
\hline $2015 / 16$ & 57,119 \\
\hline
\end{tabular}

Source: based on data from GUS (2016, p. 35).

Table. 2. HE students from Ukraine from 2005/06 through 2014/15

\begin{tabular}{|l|c|}
\hline $\begin{array}{c}\text { Academic } \\
\text { year }\end{array}$ & Number of studentsfrom Ukraine \\
\hline $2005 / 06$ & 1,980 \\
\hline $2006 / 07$ & 2,223 \\
\hline $2007 / 08$ & 2,467 \\
\hline $2008 / 09$ & 2,831 \\
\hline $2009 / 10$ & 3,499 \\
\hline $2010 / 11$ & 4,879 \\
\hline $2011 / 12$ & 6,321 \\
\hline $2012 / 13$ & 9,747 \\
\hline $2013 / 14$ & 15,123 \\
\hline $2014 / 15$ & 23,329 \\
\hline
\end{tabular}

Source: based on data from V. GIERKO (2015).
The large number of HE students from Ukraine is a source of profit for Polish HE institutions and universities as well as the cities where these students reside. The influx of foreigners may be considered a means of internationalising higher education by upgrading it to meet the needs of foreign students. It helps to attenuate the effects of the demographic low now in effect in Poland (GIERKO 2015). The influx of foreign HE students remains a source of profit for HE institutions and universities, although it also triggers critical voices in some communities. One term now used to describe the current situation in the research literature is the 'Ukrainization' of Polish HE institutions and universities ${ }^{1}$. In addition, some students ${ }^{2}$ are expressing dissatisfaction with the influx. In some cases, HE students have even been assaulted due to their ethnic identity ${ }^{3}$.

D. BARAN (2016) analyzed the image of Ukrainians in selected cases of coverage by the Polish media, while noting that the manner in which immigrants are presented directly translates into how society views them (BARAN 2016). CBOS survey studies indicate that one out of four Poles has a positive attitude towards Ukrainians, while $34 \%$ have a negative one, and $33 \%$ are indifferent (CBOS 2016). These figures are similar to those for Bulgarians and Chinese as well as Belarussians (CBOS 2016). The nationalities most liked by Poles are Czechs, Italians, and Slovaks, with $50 \%$ of Polish survey respondents indicating a positive attitude towards each of those groups (CBOS 2016). Table 3 shows a summary of positive and negative attitudes towards Ukrainians and other foreign nationals.

Table. 3. Attitudes of Polish citizens towards other nationalities

\begin{tabular}{|l|c|c|c|c|}
\hline \multicolumn{5}{|c|}{ Attitude towards selected foreign nationalities (\%) } \\
\hline nationality & $\begin{array}{c}\text { tend } \\
\text { to like }\end{array}$ & indifferent & $\begin{array}{c}\text { tend } \\
\text { to dislike }\end{array}$ & $\begin{array}{c}\text { difficult } \\
\text { to say }\end{array}$ \\
\hline Czech & 50 & 30 & 13 & 7 \\
\hline Ukrainian & 27 & 33 & 34 & 6 \\
\hline Arab & 8 & 16 & 67 & 9 \\
\hline
\end{tabular}

Source: based on data from CBOS (2016, p. 3).

Research on HE students in Kraków has shown that $45 \%$ of Polish students have a positive opinion of Ukrainian students in Poland, while $28 \%$ are indifferent, and $24 \%$ have a negative or very negative opinion (WOJTULEWSKI 2016).

\section{RESEARCH RESULTS}

Research work was undertaken in March and April 2017 in Kraków. The primary research tool consisted of a questionnaire designed for HE students from 
Ukraine majoring in the fields of tourism and recreation as well as in areas related to tourism. A total of 100 students were surveyed with 80 women and 20 men aged 18 to 28 . The main focus was on the motives behind pursuing higher education in Poland in majors related to tourism as well as career plans after graduation. The choice of Kraków as the study site was determined by its large population as well as the large influx of tourists and the fact that foreign students tend to choose Kraków very often.

The first question in the survey asked respondents to indicate their main motives for arriving in Poland. In response, $60 \%$ stated that both $\mathrm{HE}$ and work may be described as their main reasons. Only 36\% stated that $\mathrm{HE}$ was the sole reason for their stay. Finally, $4 \%$ stated that 'special projects' were their reason (Fig. 1).

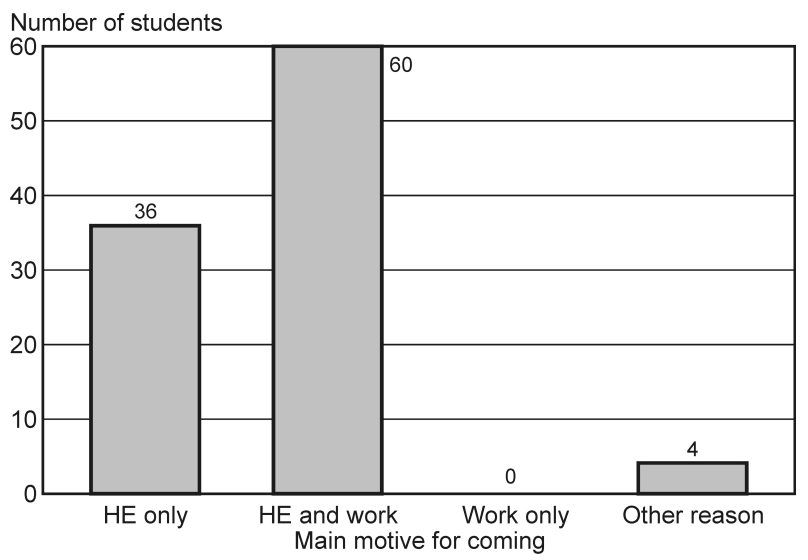

Fig. 1. Main respondent motives for coming to Poland Source: author

The second question delved deeper into the reasons for choosing to study in Poland. The students had the option of choosing any number of responses from a list of 14 including an 'other' response. The largest number $(86 \%)$ selected the desire to possess a foreign HE diploma, while $82 \%$ pointed to their desire to learn about the world. Better job opportunities characterized by the ability to pursue a real career were a reason for $74 \%$. Finally, $60 \%$ noted a desire to improve their standard of living (Fig. 2).

Satisfaction with the HE experience in Poland was expressed by $89 \%$ of students, while $11 \%$ expressed dissatisfaction.

The next issue raised was the reason for selecting tourism as a major. Most of those surveyed stated that they liked it using expressions such as 'It is to my liking' and 'I like it', as well as 'I am interested in it.' The last response did not specify whether the respondent liked the tourism major or simply liked to travel. Some of the respondents noted issues associated with future employment as well as the desire to travel. Sporadic responses included 'Because I do not like math'. The students were also asked to indicate positive and negative aspects of studying in Poland. The positive factors included obtaining a degree from a foreign university, the better quality of education available in Poland, lack of corruption, the opportunity to leave the home country, (associated with the ability to travel freely across the EU), and finally the opportunity to find a job in Poland.

Other reasons - such as?

Belief in the availabity of better social interaction

Location of country or city where college is pursued

Political consideration; lack of conflict or war

Belief in the availabity of better quality education

Belief in the opportunity

to improve one's standard

College provides on opportunity to live one's country

Opinions of other individuals

Belief in the availabity of more personal

Belief in the availabity of better career

Belief in the lack of coruption in Poland

Better quality education

Desire to learn more about the world and see new

Desire to obrtain a diploma from a foreign institution

Number of students

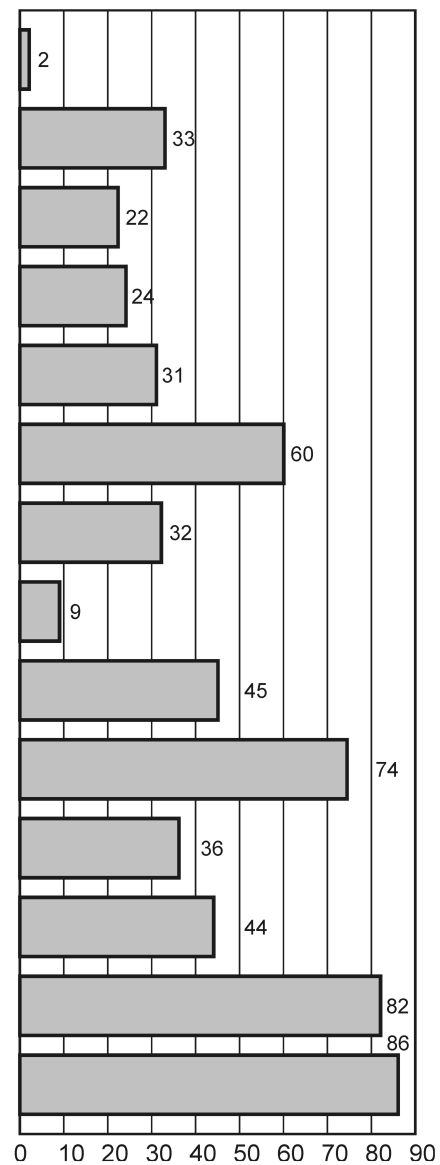

Fig. 2. Specific reasons for choosing $\mathrm{HE}$ in Poland Source: author

Negative aspects included the need to pay for $\mathrm{HE}$, few fieldtrips, few practical classes, large distances from hometowns, the presence of too many Ukrainians, complex paperwork and difficulty in obtaining a student visa. In summary, HE students from Ukraine would like to pay less for $\mathrm{HE}$ and have more practical classes. Interestingly, they would also like to see fewer Ukrainians. Of these students, $81 \%$ were also working while studying and in $58 \%$ of cases their jobs were related to tourism, mainly in the restaurant (35\%) and hotel industries (31\%) (Fig. 3).

Close to half (46) intend to remain in Poland following graduation, $43 \%$ do not know what they will do, and $11 \%$ do not intend to remain. More than $72 \%$ do not want to return to their home country, while $24 \%$ have not yet decided. Only $4 \%$ intend to return. 
Furthermore, 34\% wish to leave both Poland and Ukraine, while the majority have not made any decisions yet. The HE students surveyed who expressed a desire to go to other EU states or elsewhere listed the following countries as their preferences: Spain (19), Germany (18), USA (13), Italy (12), Great Britain (7), France/Austria/Norway (4 each), Sweden/Holland/ Japan (3 each), Switzerland/Brazil/Greece (2 each), Czech Republic and Canada (1 each). Some students selected more than one preferred destination.

Other - what type?
Tour guide
Tourism-related work
- what type?
Restaurant industry
Government work
Tourist attractions
Transportation
Hotel industry

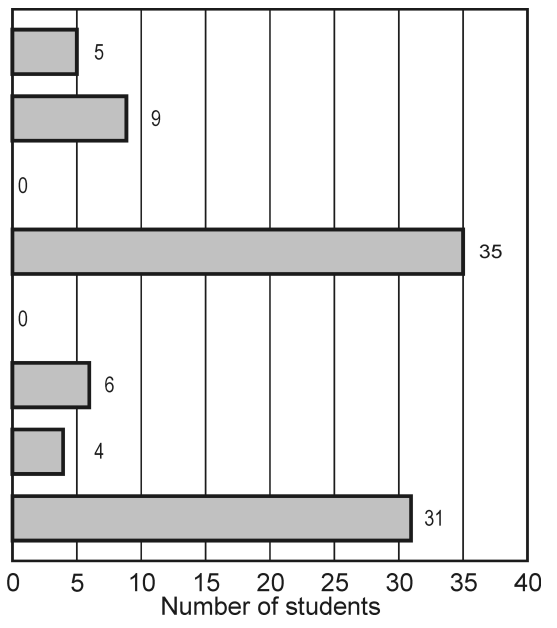

Fig. 3. Survey participants' places of employment related to the tourism industry Source: author

Most of the participants (72\%) expressed a desire to work in tourism-related industries following graduation, while $7 \%$ did not. No specific industry was listed by $20 \%$, while $1 \%$ did not respond to this question. Travel agencies as well as hotels were mentioned most often as the most desirable places of employment, while a number also listed restaurants, tour operators, convention centers, and cruise ships. Several mentioned a desire to start a business in the tourism sector. The students expressed a preferred salary range between 3,000 and 5,000 PLN per month. In addition, $89 \%$ would recommend $\mathrm{HE}$ in Poland; however, $10 \%$ would not, and $1 \%$ did not respond.

\section{DISCUSSION AND SUMMARY}

Research has shown that young people from Ukraine most often make the decision to study in Poland in conjunction with a desire to combine $\mathrm{HE}$ and work. This observation is largely consistent with trends identified by Poland's Central Statistical Office (GUS) which states that more than half of HE students from Ukraine (57\%) declare that they intend to study and work at the same time (GUS 2016). The corresponding figure in this study was $60 \%$. According to I. CHMIELEWSKA, G. DOBROCZEK \& J. PUZYNKIWEICZ (2016), half of the students who come to Poland from Ukraine are, in fact, active in the labour market and quite a few report an intention to search for work. The study also reveals that students come in large part in order to obtain a degree from a foreign $\mathrm{HE}$ institution or university - this is important to them.

These results are confirmed by research conducted in the Podkarpackie region of Poland among students from Ukraine which shows that the desire to acquire a $\mathrm{HE}$ degree from a foreign $\mathrm{HE}$ institution or university as well as to 'learn about the world' are the two main factors behind their decisions (DŁUGOSZ 2015). Most of the students worked in areas connected with their HE major or tourism. It is also noteworthy that 65,000 work permits were issued to foreigners in 2015, with more than 50,000 permits going to Ukrainian citizens (EYSIENIA 2015). GUS research shows that the most common types of jobs for Ukrainian students are in sales $(26.3 \%)$, hotel and restaurant services $(20 \%)$, and 'other' services (11.6\%) (GUS 2016).

Research has shown that young people want to work in professions associated with tourism following graduation primarily travel agencies and hotels. The preferred salary range is from 3,000 to 5,000 PLN but currently, the mean salary is 1,525 PLN (GUS 2016). For comparison, research by R. TRZCIŃSKI (2015) shows that students from Ukraine would like to earn an average of 4,155 PLN within one year of graduation. This is a net value calculated for all Ukrainian students in Poland without regard to their actual job targets.

The survey also asked about their intent to stay in Poland after graduation and 46 indicated such a desire. GUS data give a figure of $36.6 \%$, while $32.5 \%$ declared a desire to some contact with Poland. Students from Ukraine who expressed a desire to leave Poland after graduation possessed specific preferences as to where they want to go: Spain, Germany, USA, Italy or Great Britain. P. DŁUGOSZ (2015) noted a similar list of preferred destinations - USA, Germany, Great Britain and the Czech Republic. The vast majority stated their willingness to recommend $\mathrm{HE}$ in Poland. TRZCIŃSKI (2015) confirms a high degree of satisfaction with the HE experience in Poland - and writes that most students from abroad positively assess the quality of teaching at HE level. The scale used in this particular study ranged from 1 to 8 , and student satisfaction with the quality of their education stood at 6.1 for Poland as a whole (TRZCIŃSKI 2015).

One major benefit of studying in Poland was the ability to obtain a degree from a foreign $\mathrm{HE}$ institution or university. One major disadvantage was the cost of education. Foreign students did not mention the language barrier as a problem. A. GÓRSKA (2015) writes that young people from Ukraine assert that they can 
speak Polish despite using forms and words foreign to Polish in their everyday speech patterns. As many as $75 \%$ of students in this particular study rated their Polish language skills as good or very good (GÓRSKA 2015). In summary, this research is essentially a pilot study focused on foreign students in the city of Kraków. In order to obtain a bigger picture, similar analyses should be made in other major cities in Poland characterized by large student populations.

\section{FOOTNOTES}

1 See V. GIERKO (2015)

2 See http:/ /lublin.wyborcza.pl/lublin/1,48724,17036981, Stu denci_o_kolegach_z_Ukrainy_Zajmuja_miejsca_Polakom.html; accessed: 02.04.2017.

${ }^{3}$ Suspects who may have assaulted students from Ukraine, 2017, http://www.policja.pl/pol/aktualnosci/138042,Podej rzani-o-pobicie-studentow-z-Ukrainy-zatrzymani.html; acces sed: 02.04.2017.

\section{BIBLIOGRAPHY}

BARAN D., 2016, Wizerunek Ukraińców na łamach wybranej polskiej prasy, Państwo i Społeczeństwo, XVI, 1, pp. 97-116.

BERGIER J., BERGIER B., TSOS A., 2012, Aktywność fizyczna i sedenteryjny tryb życia studentek z Ukrainy, Człowiek $i$ Zdrowie, 2 (VI), pp. 124-137.

BIERÓWKA J., 2016, Opinie studentów ukraińskich na temat ich integracji akademickiej, Państwo i Spoteczeństwo, XVI, 1, pp. 199-213.

CBOS, 2016, Stosunek do innych narodów, Komunikat z badań, nr 53, Warszawa.

CHMIELEWSKA I., DOBROCZEK G., PUZYNKIEWICZ J., 2016, Obywatele Ukrainy pracujacy w Polsce - raport $z$ badania, Departament Statystyki NBP Warszawa, pp. 33.

DŁUGOSZ P., 2015., Zjawisko edukacji transgranicznej na przykładzie ukraińskich studentów na Podkarpaciu, https://www.ur.edu.pl / file/79298/Ukraińscy+studenci+na+Podkarpaciu-część+I. pdf.
GAWRON M., 2016, Postawy ksenofobiczne wśród studentów wybranych kierunków Krakowskiej Akademii im. Andrzeja Frycza Modrzewskiego, Państwo i Społeczeństwo, XVI, 1, pp. 133-148.

GIERKO V., 2015, „Ukrainizacja” polskich uczelni na tle umiędzynarodowienia kształcenia na poziomie wyższym w Polsce, Annales Universitatis Mariae Curie-Sktodowska Lublin - Polonia, XL, 2, pp. 103-119.

GUS, 2016, Szkoty wyższe i ich finanse, Warszawa, pp. 246.

GUS, 2017, Szkolnictwo wyższe w roku akademickim 2016/2017 dane wstępne, http://stat.gov.pl/obszary-tematyczne/edukacja/ edukacja/szkolnictwo-wyzsze-w-roku-akademickim-201620 17-dane-wstepne, $8,4 . h$ tml.

GÓRSKA A., 2015, Błędy studentów z Ukrainy - eliminacja i zapobieganie w grupach o zróżnicowanych możliwościach (na podstawie doświadczeń Centrum Partnerstwa Wschodniego Uniwersytetu Opolskiego), Acta Universitatis Lodziensis. Ksztatcenie Polonistyczne Cudzoziemców, 22, pp. 357-370.

KORCZYŃSKA J., KAŹMIERKIEWICZ P., 2005, Regulacja migracji zarobkowej - wyzwania dla Ukrainy w kontekście polskich doświadczeń. Doświadczenia Polski po roku 1989 jako kraju wysyłającego i przyjmującego pracowników: lekcje dla polityki Ukrainy, Warszawa.

LEŚNIAK M., 2016, Wizerunek Polski i Polaków w oczach studentów ukraińskich. Ukraińcy $\mathrm{w}$ oczach studentów polskich, Państwo i Spoteczeństwo, XVI, 1, pp. 175-198.

ŁYSIENIA M. (ed.), 2016, Cudzoziemcy w Polsce. Podręcznik dla funkcjonariuszy publicznych, Helsińska Fundacja Praw Człowieka, Warszawa, pp. 164.

Podejrzani o pobicie studentów z Ukrainy, 2017, http:/ / www. policja. $\mathrm{pl} / \mathrm{pol} /$ aktualnosci/138042,Podejrzani-o-pobicie-studentowz-Ukrainy-zatrzymani.html; 02.04.2017.

TRZCIŃSKI R., 2015, Zagraniczni studenci - czy potencjalni uczestnicy polskiego rynku pracy?, [in:] J. Konieczna-Sałamatin (ed.), Imigranci o wysokich kwalifikacjach na polskim rynku pracy. Raport z badań 2014-2015, Wyd. Idee i Fundacja „Nasz Wybór", Warszawa, pp. 175-210.

WOJTULEWSKI R., 2016, Akceptacja inności - spostrzeganie odmienności narodowej studentów z Ukrainy wśród studentów uczelni krakowskich, Państwo i Spoteczeństwo, XVI, 1, pp. 149-174.

http://lublin.wyborcza.pl/lublin/1,48724,17036981,Studen ci_o_kolegach_z_Ukrainy_Zajmuja_miejsca_Polakom. html; 02.04.2017.
Article received: 20 May 2017 Accepted: 18 July 2017 